\title{
Steamship Connections to Haapsalu and Kuressaare
}

\section{Resorts}

\author{
Teele Saar \\ Estonian Maritime Museum, Tallinn 10616, Estonia
}

\begin{abstract}
This subject and the association with the resorts and their traffic connections had developed from a formerly studied subject: "maritime connections to Haapsalu — how the vacationer arrived in the resort". After the first passenger steamer, PS Comet, was deployed in 1812 on the river Clyde, this new vessel type was used for commercial services. It was recognized quite soon that steamboats had big potential for recreational activities. This paper uses the deductive and the comparative historical methods to examine how these trends were followed in the Baltic region. Deductive method is used for explaining the common trends in using the early steamers, for example, Baltic region. Comparative history method is, on the one hand, used for showing the differences and similarities between Baltic region and Europe steamers traffic developments in 19th century. On the other hand, there is used comparison of the steamer routes and their coherence with resorts vacationer numbers. The aim of this paper is to explain how resorts were integrated into steamship schedules by shipping companies operating in the Baltic provinces of the Russian Empire.
\end{abstract}

Key words: Steamship, resort, steamer company, passenger, vacationer.

\section{Introduction}

The first passenger steamship in Europe, PS Comet $^{1}$, was used in 1812 on the river Clyde in Scotland, between Glasgow and Greenock. The first steamers were not rentable as cargo vessels, therefore, the first steamers were used for passenger traffic and using these recently introduced vessels for commercial services was a very popular practice. The early steamships had large bunkers for coal and therefore their cargo capacity was too small ${ }^{2}$. Still, steamships had something that made them more

Corresponding author: Teele Saar, M.A., manager, research field: steamship traffic in Estonia and Baltic Sea routes until 1940. E-mail: teele@meremuuseum.ee.

${ }^{1}$ The first commercially used steamer PS Charlotte Dundas was built in 1802 in Symington (Scotland) as a tug-boat. The boat was tested successfully, but did not get any commercial success. The first commercially successful steamer Clermont was built in 1807 by Robert Fulton in New York.

${ }^{2}$ The first steamers were really inefficient in their use of coal because they had single-expansion steam engines. It was not possible to refuel at sea and, for that reason, the ship had to carry all the fuel that she needed. As a consequence, there was relatively little space left for the cargo. See Armstrong, J., Williams, D. M. The Impact of Technological Change : The Early Steamship in Britain (Research in Maritime History, 47), St. John's, Nfld., 2011, p. 54. efficient than sailing ships for the first time in history, ship traffic could operate according to fixed schedules. The independence from natural phenomena made the steamers so popular among travelers. Actually, the steamers marked the beginning of tourism and traveling for the ordinary people, as for centuries, traveling had been a luxury, enjoyed mainly by the privileged classes ${ }^{3}$.

The Estonian ${ }^{4}$ coastline is about $1,200 \mathrm{~km}$ long. In the 19th century, many resorts were built along this coastline, e.g., in Haapsalu, Pärnu, Kuressaare, Pirita, Narva-Jõesuu and in other smaller places.

Haapsalu resort is the oldest in Estonia, established in 1825. It enjoyed great popularity with the Russian imperial court and even abroad. Fortunately, Dr. Hunnius, who founded the resort, kept lists of his patients. Those lists tell a lot about the patients'

\footnotetext{
${ }^{3} I$ Ibid., pp. 75-95.

${ }^{4}$ In 1721-1918, the territory of present-day Estonia was divided between provinces (also known as governorates or guberniyas) of the Russian Empire. The Province of Estonia was composed of the northern part of present-day Estonia while the Province of Livonia included the southern part of Estonia and the northern part of present-day Latvia.
} 
background and it is possible to reconstruct potential routes to the resort. Another resort was established in Kuressaare in 1840. There are some lists of guests preserved from the end of the 19th century that were published in the local Arensburger's Weekly ${ }^{5}$. These two resorts were chosen because somehow they seemed very different in their location and accessibility opportunities. A railway connection to Haapsalu was established in 1905 and the maritime connection lost its former importance. Kuressaare is located on the island of Saaremaa and the only possible connection is by water transport. Those resorts have been studied on a number of occasions by medical doctors, historians and other researchers [1-6], but the question about transport connections and how vacationers arrived to resorts has been in the background.

The question about vacationers traveling opportunities raised different topics concerning steamship traffic in the 19th century. This subject and the association with the resorts and their traffic connections had developed from a formerly studied subject: "maritime connections to Haapsalu - how the vacationer arrived in the resort" $"$. The main question of this topic is "did the steamship companies that operated in the Baltic provinces of the Russian Empire integrate the resorts into the steamer schedules?". As formerly mentioned, the resorts along coastline were year to year more popular. Did the increasing visitor numbers influenced the steamer companies to add the resorts into schedules as stopping places? On one way, the steamers gave the better opportunities for vacationers to travel to the resorts, but how did the steamship connection affect the local inhabitants?

\section{Sources}

An opportunity to answer the mentioned questions above arose from announcements of steamship

\footnotetext{
${ }^{5}$ Arensburger Wochenblatt, 1875-1885.

${ }^{6}$ Saar, T. 2011. "Maritime Connections to Haapsalu-How the Vacationer Arrived to the Resort." In Proceedings of Läänemaa Museum XIV, 16-45.
}

companies published in the Estonian local newspapers Ehstländische Gouvernements-Zeitung (1853-1905) and Arensburger Wochenblatt (1875-1911) and from the timetables of steamships in the Estonian Historical Archives [7].

The lists of vacationers who stayed in Haapsalu in 1856-1868 and Kuressaare in 1875-1885. were appreciated. These lists provided information about the vacationers' origins and an opportunity to reconstruct their possible routes.

In addition, some texts by the authors from the 19th and 20th centuries have been used so far as they concern matters related to traffic or vacationers. Examples of such texts include Die Seebäder Hapsals (Seeside Resort in Haapsalu) [8] and Целебные силы воздуха, воды и ила при Гапсале (The Power of Haapsalu Air, Water and Mud Cure) by Hunnius [9], Das Bad Arensburg auf der Insel Oesel: Ein Rathgeber für Curgäste (Spa Arensburg's on the Island Oesel: Adviser for Vacationer) $^{7}$, Arensburg und seine Kurmittel: Ein Rathgeber für Kurgäste (Arensburg's Cure: Adviser for Vacationer $^{8}$ and Der Kurort Arensburg und Seine Heilmittel: Schlammbad und Luftkurort (Resort Arensburg and Cure: Mud Bath and Spa Air) ${ }^{9}$.

Personal points of view have been introduced by considering memories and writings from authors from the investigated time, e.g., notes of pastor Adolph Eduard M. von Hörschelmann of Haapsalu and articles published in Arensburger Wochenblatt: Von Riga über Baltischport nach Dorpat (Arensburg's Weekly: From Riga via Baltischport to Dorpat) [10] and Kurort Arensburg [11].

\section{Voyage to the Resort}

The first commercial steamboat in Europe, PS Comet, began carrying passengers down the river Clyde to Helensburgh in 1812 . The early steamboats

\footnotetext{
${ }^{7}$ Holzmayer, J. B. 1880. Spa Arensburg's on the Island Oesel: Adviser for Vacationer. Arensburg: Th. Lange, pp. 72-80. ${ }^{8}$ Schulz, V. G., Karstens, G. E., Bursian, R. R., and Meivald, R. G. 1902. Arensburg's Cure: Adviser for Vacationer. pp. 55-57. ${ }^{9}$ Kimmel, N. 1912. Resort Arensburg and Cure: Mud Bath and Spa Air. St. Petersburg: Imp. School of Deaf, p 14-16.
} 
had a limited cargo capacity. Therefore, they were used for carrying passengers and high-value freight. Their advantage over sailboats was greater reliability, as a steamer could arrive and depart at predetermined times. The potential of steamboats for engagement in recreational activity was quickly recognized. The developments varied between ports though, depending on the options of promoting tours, offering scenic voyages and providing transport connections to resorts or sightseeing spots [12].

After the introduction of the first steamboat in Britain, steamer connections spread throughout Europe in a few decades. Steamer connections between ports of the Russian Empire ${ }^{10}$ and between Russian and foreign ports became more and more topical. The first steamship that visit Estonian ports was the British steamer George IV in 1827. The purpose of her voyage was to start a route connection between England and Russia. The first paddle steamer to visit Kuressaare was the Graf Gancrin in 1832 with tradesmen on board from Riga (capital of the Province of Livonia and now Latvia), who were on a cruise to Ruhnu, Kuressaare and Pärnu [13].

In earlier studies, it has always been noted that vacationers from St. Petersburg, Russia, arrived in the resort of Haapsalu almost exclusively by train. However, regular train traffic between Haapsalu and Keila did not begin until 1905 while the resort in Haapsalu had been established in 1825. These two statements raise the question-how did the vacationers arrive at the resort before the regular train traffic started in 1905. The resort of Kuressaare is located on the island of Saaremaa and could only be reached by water transport. Little towns like Haapsalu and Kuressaare did not have any direct steamship connection to foreign ports. And this meant that vacationers from abroad had to first arrive in St.

\footnotetext{
${ }^{10}$ The first steamboat in Russia was the Elizaveta in 1815 , built by Charles Baird. That steamboat introduced steamship-building in Russia, although Emperor Nicholas I did not believe in a success of steamers and considered them to be a whim of fashion that would come and go. Stokeby, R. 1993. Baltimere blokaad a. 1854-1855, Sõdur 43, pp. 322-324.
}

Petersburg, Riga or Tallinn ${ }^{11}$. For reconstructing the vacationers voyages, it is very important to investigate the maritime connections between those towns and resorts. On the basis of certain sources, it is possible to reconstruct the voyages to the resorts as from the beginning of steamer traffic between St. Petersburg and the Baltic provinces. Earlier traffic had been by sail ships, which depended on wind strength and direction. The connection between St. Petersburg and Riga was started in $1844^{12}$. According to an statement in the Livländische Amtsblatt paper, the steamboats Daria and Riga (110 and 140 horsepower, respectively) were plying between St. Petersburg and Riga once a week, departing from both directions at 3 p.m. every Saturday $^{13}$. Although those first steamboats did not have any resorts as their destinations, they marked the beginning of the most important connection in the Baltic provinces of Russia for the next 70 years.

Information about Baird's company, which had started operating in the middle of the $1840 \mathrm{~s}$, has been found until 1856. In 1853, SS (steamship) Newa and SS Alexandra were operating on the route between St. Petersburg, Tallinn, Haapsalu, Muhu and Riga ${ }^{14}$. SS Thetis and SS Naslednik, belonging to a company called Mediator, operated in $1850 \mathrm{~s}$ in two different directions: St. Petersburg-Tallinn-Haapsalu-SaaremaaRiga-Liēpaja and St. Petersburg-Tallinn-Haapsalu-

\footnotetext{
${ }^{11}$ St. Petersburg and the provincial capitals Riga and Tallinn had steamship connections to Helsinki, Stockholm, Szczecin (Stettin), Lübeck, Copenhagen and London. In 1914, it was possible to use steamships for travelling from Halifax or New York City to Liepāja (Libau), Latvia, and from Liepāja to St. Petersburg with stops in both Kuressaare and Haapsalu. Ehstländisch Gouvernements-Zeitung (Estonian Province Journal), 1853-1905; Arensburger Wochenblatt (Arensburg's Weekly), 1875-1911; Time Schedule of Russian-America steamers in 1914: The Only Direct Connection between North-Amerca and Russia and Baltic Line: The Most Comfortable Connection between Baltic Ports, East Asiatic Co. Ltd., St. Petersburg, 1914.

${ }^{12}$ The first steamer connection to an Estonian port was the connection between Tallinn and Helsinki, Finland, which started in 1837 .

${ }^{13}$ Livländisches Amtsblatt (Livonian Official Gazette), March $29,1844$.

${ }^{14}$ Ehstländische Gouverments-Zeitung (Estonian Province Journal), March 30, 1853, May 11, 1853, April 23, 1856 and April 30, 1856
} 
Moonsund-Riga. The last announcement about Mediator's steamboats is from 1857. Those steamers did not berth at Haapsalu because the port was too shallow. Instead, they stopped near the islet of Harilaid $^{15}$ between the island of Hiiumaa and Haapsalu. The passengers were transported to Haapsalu by the Wariag, a small screw steamboat. The Wariag operated on a route between Haapsalu, the village of Heltermaa (on the island of Hiiumaa), the Väike väin strait and the village of Virtsu (in western Estonia), and after 1856, on the Haapsalu-Heltermaa route ${ }^{16}$. As we could see, the connection between St. Petersburg and Riga did not include any direct transport to the Haapsalu resort, nor to Kuressaare. The steamers stopped in Moonsund and, after 1856, in Kuressaare roadstead.

A route to the resort has been described by Dr. Karl Arthur Hunnius in the 1850s as follows: "those who want to get to the Haapsalu resort fast and inexpensively ${ }^{17}$ [9] should arrive by sea. Anyone not afraid of voyaging can take a boat to Tallinn and travel by Baird's steamboat onwards to the islet of Harilaid, whence the mail boat will take him to the resort town. Travelling by post-horses would be as expensive and uncomfortable. The trip will last $8 \sim 10$ h without the stops"18.

\footnotetext{
${ }^{15}$ Harilaid is a little islet in Hari strait (between the islands of Hiiumaa and Vormsi). In 1840, an inn was established there and the Kimber family moved to the islet as innkeepers. In 1849 , the owner of Suuremõisa estate built a beacon on the islet and the family also became lighthouse-keepers. They lived there until 1939, when they were relocated as a consequence of the Soviet-Estonian mutual assistance treaty, whereby Soviet military bases were placed in Estonia. Luige, A. 1982. Eesti Tuletornid: Fakte ja Meenutusi (Estonian Lighthouses: Facts and memories). Tallinn, p. 85.

${ }^{16}$ Ehstländische Gouvernements-Zeitung, March 30, 1853, May 11,1853 , June 15, 1853, June 25, 1856, July 2, 1856 and May 20, 1857.

${ }^{17}$ In 1853 , the voyage from St. Petersburg to Haapsalu on board a steamship cost 12 silver roubles for the 1 st class, 8 silver roubles for the 2 nd class and 4 silver roubles for the 3 rd class. The voyage from Riga cost 9, 5 and 3 silver roubles, respectively. The trip from Tallinn to Haapsalu by post-horses cost 5 roubles per horse, plus a fee for changing horses, amounting to 3 kopecks per horse. In 1859, the trip by post-coach cost 18 silver roubles per seat (Ehstländische Gouvernements-Zeitung, June 15, 1853 and May 4, 1859).

${ }^{18}$ Hunnius, K. A. 1853. Die Seebäder Hapsals, Reval, p. 69.
}

In the $1850 \mathrm{~s}$, traveling to the resorts of Haapsalu and Kuressaare became easier and more comfortable as new steamship companies came to the market. At the end of the 1850 s, a new company (probably the predecessor of Riga Steamship Company) started to operate on the route St. Petersburg-Tallinn-Haapsalu-Moonsund-Riga, using SS Hero and SS Leander ${ }^{19}$. From 1858 onwards, the maritime connection between St. Petersburg and Riga was operated by two steamer companies, namely Rigaer Dampfschiffahrts-Gesellschaft (based in Riga, sometimes also referred to as the "Riga Steamship Company") and Österbottniska Ångfartygs Aktiebolag (based in Turku, Finland, the name could be translated from Swedish as the "East Bothnia Steamship Company"). The former operated on that route for decades. The Riga Steamship Company started to operate on the route St. Petersburg-TallinnHaapsalu-Kuressaare-Riga-Ventspils-Liēpaja with SS Admiral, SS Thetis and SS Leander. The Finnish Company'S SS Alexander II and SS Grefve Berg operated on the route St. PetersburgTallinn-Haapsalu-Riga in 1858-1859.

In the 1850s, ship traffic on the Baltic Sea was for a while interrupted by the Crimean War. The blockade imposed by the English and French navies stopped all traffic in Russia's Baltic sea ports. In 1854, the ship routes between Riga and St. Petersburg remained closed. There were no statements in newspapers about steamship traffic in 1854-1855. This made travelling to the resorts more difficult and pastor Hörschelmann noted in 1854 that "because of the menace of war, there are only a few vacationers, such as some noble families". To recognize what was the influence of the interrupted maritime connection, it is needed to explain the impact of vacationer numbers. What is indicated by the lists of vacationers of that time? Lists from the Haapsalu resort show a tenfold decrease in the number of vacationers in 1854 [8, 14].

From the 1860 s to the 1910 s, steamer traffic between St. Petersburg and Riga was dominated by the Riga

\footnotetext{
${ }^{19}$ Ehstländische Gouverments-Zeitung, June 3, 1857.
} 
Steamship Company. In the second half of the 1860s, the steamer Nadeschda, owned by a merchant and manufacturer called Rottermann, was operating on the same route. In 1867, the Riga Steamship Company had already four (SS Admiral, SS Alexander II, SS Leander and SS Riga) steamers and in 1872, it had five steamers (SS Admiral, SS Leander, SS Alexander II, SS Riga, SS Düna and SS Newa) ${ }^{20}$ [7].

The Haapsalu and Kuressaare resorts were quite popular in the second half of the 19th century, but both had the same problem: they were situated at shallow bays, where steamers had difficulties berthing. Therefore, the steamers had to stay at a greater distance. The berthing problem was solved in Haapsalu in 1861, when a new port was opened, and in Kuressaare in $1872^{21}$ [13]. However, some bigger steamships still could not enter the small ports and stop on the roadsteads, from which the passengers were taken to the resort by small steamboats. For example, we could find some announcements about steamers of the Riga Steamship Company operating on the route Riga-Kuressaare-Haapsalu-Tallinn-St. Petersburg but SS Newa did not enter the port of Haapsalu. Instead, she stopped near the islet of Harilaid and let the mail steamer Progress transport the passengers to the shore ${ }^{22}$ or the passengers would be taken by the steamboat Margarethe from the port of Kuressaare (now Roomassaare port), located at the entrance to Kuressaare bay, to the town of Kuressaare ${ }^{23}$.

A shipping company called Osilia ${ }^{24}$ was established in Kuressaare in 1873. At first, it had just

\footnotetext{
${ }^{20}$ Forwarding Company Thomas Clayhills \& Sohn. Ship Traffic Announcements (1833-1914). Ehstländische Gouvernements-Zeitung, May 11, 1867.

${ }^{21}$ Haapsalu Kirikukroonika (Haapsalu's Church Chronicle), p. 43.

${ }^{22}$ Arensburger Wochenblatt, May 21, 1909.

${ }^{23}$ Arensburger Wochenblatt, June 16, 1892.

${ }^{24}$ The first request from the Oesel Noble Corporation (Oeselsche Ritterschaft) to establish some kind of connection between the island of Muhu and the mainland was sent in the mid-1840s but did not get any attention. In 1848, the noble corporation submitted another request to establish a steamship company, since other companies already operating did not stop in Kuressaare. That second request went without attention too. Pao, 1999, pp. 90-91.
}

one steamer, SS Constantin, which operated on the routes Kuressaare-Moonsund-Haapsalu-Paldiski and Kuressaare-Riga $^{25}$. From 1881 onwards, the steamship connection was run in cooperation with Baltische Eisenbahn (the local railway company, the name could be translated from German as "Baltic Railway") and was complemented by railway connections to Tallinn, Tartu and St. Petersburg via the port of Paldiski on the north-western coast of Estonia. In 1884, the steamship connections were united into the route Riga-Kuressaare-Moonsund-HaapsaluPaldiski $^{26}$. In 1911, the company bought a new steamer, SS Osilia, which replaced SS Constantin on the above-specified connection in 1911 at some time between the beginning of the navigation season ${ }^{27}$ and the middle of June ${ }^{28}$.

Here is a passenger's description about his voyage from Riga to Paldiski (Baltischport) on board SS Constantin: "I have to say that, on the morning of June 26, I stepped on board with some doubts. I had indeed heard a lot about the stately interior but when I saw the big rooms, beautiful furniture and elegant equipment, I was still quite surprised. The ladies' saloon was the most elegant one I have ever seen on board a passenger ship in our waters. Nothing has been forgotten here to make the passenger feel comfortable and pleasant, the saloon is even equipped with a piano" ${ }^{, 29}$.

In 1911, another shipping line, the Russian East Asiatic Steamship Co., entered the market and began to ply between Riga and St. Petersburg. The company had three steamers, SS Libau, SS Petersburg, and SS Astraea, operating on the routes Kuressaare-Kuivastu-Haapsalu-Tallinn-St. Petersburg and Kuressaare-Riga-Liēpaja ${ }^{30}$. In 1914, just before the outbreak of the First World War, the Russian East

\footnotetext{
${ }^{25}$ Arensburger Wochenblatt, July 23, 1875; April 28, 1876; May 11, 1877; June 23, 1881; May 11, 1882; June 21, 1883.

${ }^{26}$ Arensburger Wochenblatt, May 22, 1884.

${ }^{27}$ Arensburger Wochenblatt, May 3, 1911.

${ }^{28}$ Arensburger Wochenblatt, June 14, 1911.

${ }^{29}$ Arensburger Wochenblatt, July 20, 1877; July 27, 1877.

${ }^{30}$ Arensburger Wochenblatt, June 2, 1911; June 28, 1911.
} 
Asiatic Steamship Co. was operating SS Konstantin, SS Imperator Nicolai II, SS Moon and SS Düna on the route St. Petersburg-Narva-Tallinn-HaapsaluKuivastu-Kuressaare-Pärnu-Riga-Ventspils-Liēpaja ${ }^{31}$.

It is noteworthy to mention that seaside resorts were integrated into steamer companies' schedules from the beginning of the 1850s. The steamship traffic, in turn, supported the active life of the resort towns. The steamer companies were interested in smooth and well-functioning traffic to and from those little towns. They had to struggle for their position in passenger traffic, and only the bigger companies offering something different (e.g., Osilia, which provided the connection in cooperation with the Baltische Eisenbahn Railway Company) survived or operated for a long term. The attractiveness of resorts for the steamer owners and companies was because of the popularity of the resort itself.

\section{Vacationers and Passengers}

Focusing on the issue of passenger traffic, there is a need to pay attention to the passengers themselves. The aforementioned Estonian seaside resorts were very popular in the late 19th and early 20th centuries. In examining the steamer traffic, we have to ask, on the one hand, about who the passengers were. And on the other hand, we can also ask if the steamer traffic opened the world to the communities living in those resorts. The statement-resorts were very popular - does not say any word about the origin of the vacationers, so to understand who were the passengers on those formerly mentioned routes is needed to enlighten the starting points of the voyages.

The oldest resort in Estonia was built in Haapsalu in 1825 by Dr. Carl Abraham Hunnius (1797-1851). In the $1830 \mathrm{~s}$, the resort was visited by over 100 vacationers and, in the middle of the century, just before the Crimean War (1853-1856), by more than

\footnotetext{
${ }^{31}$ Time schedule of Russian-America steamers in 1914: the only direct connection between North-America and Russia and Baltic Line: the most comfortable connection between Baltic ports, East Asiatic Co. Ltd., St. Petersburg, 1914.
}

1,000 vacationers per season (from June to September $)^{32}[8,14]$. Most of them were from St. Petersburg (mostly noble and military persons), another major group being noblemen from the Provinces of Estonia and Livonia. The resort was known beyond the borders of the Russian Empire. Although the proportion of foreign vacationers was small, their origins are remarkable: Germany (mostly Northern Germany: Hannover, Hamburg, Altona, Baden, Berlin, Ratzeburg and Dresden), Great Britain, France, Netherlands, Switzerland, Austria, Rome, Stockholm and even Constantinople ${ }^{33}$.

The resort in Kuressaare was established in 1840 by Jakob Georg Weise (1808-1858) ${ }^{34}$. The annual number of visitors exceeded 100 for the first time in 1853. In 1878 , the resort was visited by more than 500 and, in the early 20th century, by more than 1,000 vacationers annually ${ }^{35}$ [15]. As in Haapsalu, most of the vacationers came from St. Petersburg or Riga. Kuressaare was not so well known abroad as Haapsalu and, therefore, many vacationers were from the nearer regions like Livonia, Lithuania and Poland. The farthest points of origin of vacationers were Moscow, Smolensk and Odessa. There were also some vacationers from northern Germany but the list of countries was less diverse than in the case of Haapsalu ${ }^{36}$.

It can be seen that, from the information concerning the vacationers' origins, most of them had started their voyage to the resort from St. Petersburg or Riga. However, how did the steamer traffic influence the local life and did it open the world for ordinary people, too? In a way, the steamships delivered the world to

\footnotetext{
${ }^{32}$ List of in Haapsalu Resort Arrived Vacationers, Reval, 1856-1868 (handwritten lists of vacationers, probably compiled by Hunnius, K. A.).

${ }^{33}$ Liste der in Hapsal angekommende Badegäste, Reval, 1856-1868.

34 "Turism ja Puhkemajandus Pärast Taasiseseisvumist (Tourism and Recreation Management After the Regaining of Independence)" by Soorsk, M., Muru, L., and Eelma, K. 2007, p. 754 .

${ }^{35}$ Ibid., pp. $759-760$

${ }^{36}$ Arensburger Wochenblatt, 1875-1885.
} 
the resort, as many of the vacationers lived side by side with the townspeople during the season ${ }^{37}$ and, naturally, influenced their manners and behavior. Perhaps some of the locals could later move to St. Petersburg or Riga and start working in vacationers' families.

The second half of 19th century was a time of economic and social changes. As a result, the opportunity to travel from one place to another should not be underestimated. An important law that influenced the ordinary people in Russia's Baltic provinces was the Passport Act, adopted in 1863, that gave every person over 21 years of age an opportunity to move beyond the borders of their home county. As we know, a lot of ordinary people started to work in factories in towns like Tallinn or Riga or even St. Petersburg $^{38}$. The resorts discussed here did not have any factories nearby. The steamer traffic presented a great opportunity for the locals and also the cheapest way of long-distance travel in those times.

We should not forget about the residents of the resort towns and the surrounding areas, especially the tradesmen and the local nobility. They had to communicate with the provincial capitals and St. Petersburg on many occasions and the opportunity to get there easier and more comfortable was a great advantage. Most of the nobility moved to their city houses for the wintertime and took much movable property with them ${ }^{39}$. Transport of the property by the fast steamships was much handier than by road. Moreover, most of the nobility in the Baltic provinces were Baltic Germans who had strong ties with Germany (for example, their children studied in

\footnotetext{
${ }^{37}$ Liste der in Hapsal angekommende Badegäste, Reval, 1856-1868; Arensburger Wochenblatt, 1875-1885.

${ }^{38}$ Bruno Pao has noticed that in 1875 , after the establishment of the Osilia steamship company, the number of housekeepers, manufacture workers and temporary workers increased three times. Pao, 1999, p. 92.

${ }^{39}$ Pastor Hörschelmann has described the arrival of the imperial steamer with moveable property on June 4, 1859. The imperial family, as well as other vacationers, used to stay in a resort for a month or even two. Ordinary vacationers did not, of course, have a luggage of such dimensions but arrived with many belongings, too.
}

German universities, not to mention the trade and cultural connections). The steamer lines offered them much wider opportunities for travel.

\section{Conclusions}

In the second half of the 19th century, the Haapsalu and Kuressaare resorts were popular in the Russian Empire and even abroad. From the 1840s and 1850s onwards, their visitor numbers increased every year, giving rise to a demand for better transport connections. Therefore, it is noteworthy to mention that passenger traffic to and from the Baltic provinces of Russia had much the same motives as in Britain, where the steamers were first introduced in Europe.

The first notice about regular steamer traffic between St. Petersburg and Riga (that we know of) dates back to 1844. Only a decade later, different steamer companies had to struggle for an opportunity to operate this route. When we look at which ports were integrated into the steamship routes, it can be seen quite well that the resorts were included in the schedules of most shipping companies. Every new company attempted to offer something new: either more comfortable ships or routes combined with railway, etc..

Why the steamer companies added the resorts into the steamship routes? The resorts vacationer numbers were growing year by year and therefore the supply was created by demand at first. On the other hand, the steamer companies were private enterprises and operating steamers were not very cheap, so they needed the routes, where they got as much passengers as possible. Resorts had a really strong position in the steamship schedules from the 1850 s on. Their position was so strong that, when the steamer connections were interrupted during the Crimean War, the vacationer number decreased about tenfold. The steamship connection also influenced the local communities development. On one hand, the vacationers influenced the local community behavior and manners during the resort season. On the other 
hand, steamer connections gave the locals better voyage opportunities. The latter opportunity was more relevant for the local tradesmen and nobility but also for the ordinary people, who could now temporarily leave for bigger towns to work there. The importance of the steamer traffic for the local communities was similar to the meaning of railway a few decades later for the communities who were connected by railway traffic. Given that the influence of steamer traffic on the local people and their mentalities has not been studied extensively, it will perhaps offer an interesting study for historians in the future.

\section{References}

[1] Alver, H. 1922. Eesti kuurort Haapsalu (Estonian Resort Haapsalu). Haapsalu: KÜ Lääne. (in Estonian)

[2] Martinson, M. 1975. Haapsalu kuurort (Resort of Haapsalu). Tallinn: Eesti Raamat. (in Estonian)

[3] Raudver, G. R. 1979. Haapsalu Läbi Aegade ja Inimeste (Haapsalu History Through the Ages and Persons). Tallinn: Eesti Raamat. (in Estonian)

[4] Soorsk, M. 1999. "Suvituselust vanas Kuressaares (Summer Time in Old Kuressaare)". In Saaremaa Muuseum: Kaheaastaraamat 1997-1998 (Annals of Saaremaa Museum 1997-1998), edited by Pesti, O. K. Kuressaare: Saaremaa Muuseum. (in Estonian, summaries in English)

[5] Soorsk, M., Muru, L., and Eelma, K. 2007. "Turism ja Puhkemajandus Pärast Taasiseseisvumist (Tourism and Recreation Management after the Regaining of Independence)." In Saaremaa 2, Ajalugu, Majandus, Kultuur (Saaremaa II: History, Economy, Culture), edited by Jänes-Kapp, K., Randma, E., and Soosaar, M. Tallinn: Koolibri. (in Estonian)
[6] Voll, A. 2005. "Haapsalu Kuurort Aastatel 1825-1991 (Haapsalu Resort in Years 1825-1991).” B.A. thesis, University of Tartu. (in Estonian)

[7] EAA (Estonian Historical Archives). nd. 4924. 1, 4470. Timetables of Steamships from 1833-1914. Estonia: EAA.

[8] Hunnius, K. A. 1853. Die Seebäder in Hapsals (Seaside Resort in Haapsalu). Reval: Linfors' Erben. (in German)

[9] Hunnius, K. A. 1857. The Power of Haapsalu Air, Water and Mud Cure. St. Petersburg: Maritime Ministry. (in Russian)

[10] Witout Author (Anonymous Letter). 1877. "Von Riga über Baltischport nach Reval.”(From Riga via Baltischport to Reval) Arensburger Wochenblatt July 27. (in German)

[11] Nolcken, G. 1907. "Über die Fahrt nach Arensburg (About Journey to Arensburg)." Arensburger Wochenblatt, April 26. (in German)

[12] Armstrong, J., and Williams, D. M. 2011. "The Impact of Technological Change: The Early Steamship in Britain.” In Research in Maritime History 47, edited by Fischer, L. R., and Hennessey, M. M. St. John's New Foundland: International Maritime Economic History Association.

[13] Alver, H. 1935. "Haapsalu arvudes (Haapsalu in Numbers).” Lääne Elu (Lääne Life), February 8. (in Estonian)

[14] Pao, B. 1999. "Kuressaare ja Riia Merelised Sidemed 19. Sajandil (Maritime Connections between Kuressaare and Riga in 19th Century)." In Saaremaa Muuseum: kaheaastaraamat (Annals of Saaremaa Museum 1997-1998), edited by Pesti, O. K. Kuressaare: Saaremaa Muuseum. (in Estonian, summaries in English)

[15] Prümmel, J. 1923. Eesti Tervismuda-ja Merekuurordid : Haapsalu, Kuresaare, Pärnu, Narva-Jõesuu, Võsu, Loksa, Käsmu, Pirita (Estonian Mud and Seaside Resorts: Haapsalu, Kuressaare, Pärnu, Narva-Jõesuu, Võsu, Loksa, Käsmu, Pirita and Others). Tartu: K/Ü Loodus. (in Estonian) 